DOI 10.18551/rjoas.2021-04.17

\title{
GROWTH AND PRODUCTION OF RICE (ORIZA SATIVA L) IRRIGATION FIELD AT VARIOUS DOSAGE OF DIFFERENT PHOSPHORUS FERTILIZER
}

\author{
Herman* \\ Department of Agriculture, Makassar Islamic University, Indonesia \\ Musa Y. \\ Department of Agriculture, Hasanuddin University, Indonesia \\ Zubair $\mathbf{H}$. \\ Department of Soil Science, Hasanuddin University, Indonesia \\ Syatrianty \\ Department of Agriculture, Hasanuddin University, Indonesia \\ `E-mail: andrie.dty@uim-makassar.ac.id
}

\begin{abstract}
This study aimed to determine the growth and production of irrigated lowland rice by using different doses of phosphorus fertilizer. This research was conducted in the form of a 2-factor factorial experiment which was compiled based on a Randomized Block Design (RBD) With the following treatment arrangements: f0 without the use of SP36 (control), f1 SP36 $30 \mathrm{~kg} /$ ha, f2 SP36 $60 \mathrm{~kg} / \mathrm{ha}, \mathrm{f} 3$ SP36 $90 \mathrm{~kg} / \mathrm{ha}, \mathrm{f} 4$ SP36 $120 \mathrm{~kg} / \mathrm{ha}$, f5 SP36 $150 \mathrm{~kg} / \mathrm{ha}$, f6 SP36 $180 \mathrm{~kg} / \mathrm{ha}$ and f7 SP36 $210 \mathrm{~kg} / \mathrm{ha}$. The study was conducted with 8 treatments that were repeated 3 times so that there were 24 observation units. The results of this research were, the giving phosphorus fertilizer did not have a significant effect on plant height, number of productive tillers, number of grain / panicle and weight / 1000 seeds. Giving a dose of 180 $\mathrm{kg} / \mathrm{ha}$ of phosphorus fertilizer could reduce the number of empty seeds / panicles in rice plants. Giving a dose of phosphorus fertilizer of $150 \mathrm{~kg} /$ ha could increase the dry weight of the harvest / plot and the dry weight of the harvest / ha of rice plants.
\end{abstract}

\section{KEY WORDS}

Rice plants, fertilization, elements of phosphorus, irrigated, rice fields.

At this time, the rice productivity achieved by farmers tends to be sloping. The addition of farm inputs tends to be unbalanced with the produced output. The use of production technology packages which do not consider aspects of land carrying capacity is one of the causes of the limited increase in agricultural production so far. Based on BPS data, 2018 national rice production for the last 5 years were 70,846,000 (2014), 75,398,000 (2015), $79,355,000$ (2016), 81,149,000 (2017), 83,037,000 (2018). This data showed that the rice production was slowing down and can threaten national food security, given the level of food demand that tends to increase along with population growth. In future, the quality of food which is free from various chemical residues become theown challenge in meeting food needs. The real challenge for agricultural development in the future is the decreasing carrying capacity of land caused by reduced level of soil fertility and high levels of residual organic matter and chemical substances. Excessive land degradation due to continuous tillage resulting in decreased agricultural production Adimihardja (2008).

Fertilization is one component of technology that still plays an important role in increasing crop productivity especially for rice. The use of inorganic fertilizers is a must considering the condition of agricultural lands which are getting poorer in nutrients in the soil. Meanwhile, on the other hand, the land is expected to produce maximum food production. Sugiatmoet. al.., (2001) stated that the use of organic and inorganic fertilizers with the correct 
dosage and balance can increase the availability of nutrients in the soil which will help increase rice production optimally.

Fertilizer as a means of production for rice cultivation plays a very important role in increasing the productivity of lowland rice fields. The use of inorganic fertilizers which carried out by farmers based on recommendations from the agricultural office tends to increase from year to year; this is due to the increasing intensity of planting and the high response of rice plants to fertilization. The high use of inorganic fertilizers and pesticides has had a negative impact on the residual capacity of active materials in crops and land.

Phosphorus is a macro nutrient needed by plants and it is essential and there is no element that can replace its role in plants. Plants must require a sufficient amount of elemental phosphorus for normal growth while the function of phosphorus in plants is in the processes of photosynthesis, respiration, energy transfer and storage, cell division and enlargement and other processes in plants Salisbury and Ross, (1995).

Phosphorus plays an important role in most enzyme reactions that depend on phosphorylase because phosphorus is part of the cell nucleus, so it is important in cell division and also for the development of meristem tissue. Thus, phosphorus can stimulate the growth of young plant roots, accelerate flowering and ripening of fruit, seeds or grain Zubaidah, Y and Munir, R., (2007).

The use of phosphorus by farmers has been quite high, whether given in the form of a single fertilizer, namely SP36 or in a compound form in the form of NPK, this is done because Phosphorus is very useful for plants considering it functions to stimulate root growth, especially in the early stages of growth, accelerate flowering, ripen seeds and fruit. If the plant is deficient in phosphorus, the phosphorus elements present in the old tissue will be mobilized to the young tissue, so that in the old tissue will be deficient first, as well as when the plant has entered the generative phase (maturity). Meanwhile, on the other hand, the use of high phosphorus will inhibit the absorption of other nutrients, especially micro nutrients such as iron (Fe), copper ( $\mathrm{Cu}$ ) and zinc $(\mathrm{Zn})$, affect fruit quality and the accumulation of large amounts of phosphorus in the soil. Based on the description above, research was carried out to assess the growth and production of irrigated lowland rice at various different dosages of phosphorus fertilizer.

\section{MATERIALS AND METHODS OF RESEARCH}

This research was conducted at a technical irrigation rice field location in the Benteng Sawitto village, Paleteang district, Pinrang Regency. Lasts from May to September 2019.

The materials used were Inpari 42 rice seeds, Urea fertilizer, SP36, $\mathrm{KCl}$, and Carbofuran Insecticide. While the tools used werehand tractors, hoes, machetes, buckets, hands prayers, scales, gauges, documentation tools and writing instruments.

This research was conducted in the form of a factorial experiment which was arranged based on a randomized block design (RBD). With the following treatment arrangements:

- $\mathrm{F} 0=$ Urea $250 \mathrm{~kg}$, SP36 0 NPK $150 \mathrm{~kg}, 1$ ton of manure, 2 tons of straw/ha;

- $\mathrm{f} 1$ = Urea $250 \mathrm{~kg}$, SP36 30 NPK $150 \mathrm{~kg}, 1$ ton of manure, 2 tons of straw/ha;

- $\mathrm{f} 2$ = Urea $250 \mathrm{~kg}$, SP36 60 NPK $150 \mathrm{~kg}, 1$ ton of manure, 2 tons of straw /ha;

- $\mathrm{f} 3$ = Urea $250 \mathrm{~kg}$, SP36 90 NPK $150 \mathrm{~kg}, 1$ ton of manure, 2 tons of straw/ ha;

- $\mathrm{f} 4$ = Urea $250 \mathrm{~kg}$, SP36 $120 \mathrm{~kg}$, NPK $150 \mathrm{~kg}, 1$ ton of manure,2 tons of straw /ha;

- $\mathrm{f} 5$ = Urea $250 \mathrm{~kg}$, SP36 $150 \mathrm{~kg}$, NPK $150 \mathrm{~kg} / \mathrm{ha}$ (regional recommendation);

- $\mathrm{f} 6=$ Urea $250 \mathrm{~kg}$, SP36 $180 \mathrm{~kg}$, NPK $150 \mathrm{~kg}, 1$ ton of manure, 2 tons of straw /ha;

- $\mathrm{f} 7$ = Urea $250 \mathrm{~kg}$, SP36 $210 \mathrm{~kg}$, NPK $150 \mathrm{~kg}, 1$ ton of manure, 2 tons of straw/ ha.

The study was conducted with 8 treatments that were repeated 3 times so that there were 24 observation units.

The seeds used were the Impari42 variety, where the nursery was done around the planting area, and then the soil was processed for the nursery preparation. 
Soil processing was carried out before planting using a tractor. This was done to cultivate and flip the soil and then destroy the chunks of soil to form a mud structure and then make a plot or plot.

The area of the plot was made $3 \times 3 \mathrm{~m}$, between the plots a small bund was made so that water from one plot and the other did not flow to one another.

Planting was carried out by planting seeds directly with the paralon system which previously had the seeds soaked for 12 hours, then planting with a spacing of $20 \times 20 \mathrm{~cm}$.

Fertilization of straw organic matter and manure were given earlier during soil cultivation then SP36 1/2 parts. Furthermore, the second fertilization was carried out when the plants were 2 weeks after planting by giving 1/2 parts of urea, SP26 and NPK. Furthermore, the third fertilization was carried out when the plants were 4 - 5 weeks after planting by giving $1 / 2$ parts of urea and NPK.

Maintenance processes were included: embroidery, weeding, water management and pest and disease control.

Observation Parameters:

- Plant height $(\mathrm{cm})$ was observed when panicles were appeared;

- Number of productive tillers;

- The number of grains per panicle;

- Grain weight per 1000 seeds;

- Percentage of empty grain;

- Yields of harvested dry grain per plot;

- Yields of harvested dry grain tons per ha.

\section{RESULTS AND DISCUSSION}

The results of observations of plant height at the appearance of panicle and its variability are presented in the Appendix 1 and 2 . The analysis of variance showed that the dose of phosphorus treatment had no significant effect on plant height at the appearance of rice panicles.

plant height(cm)

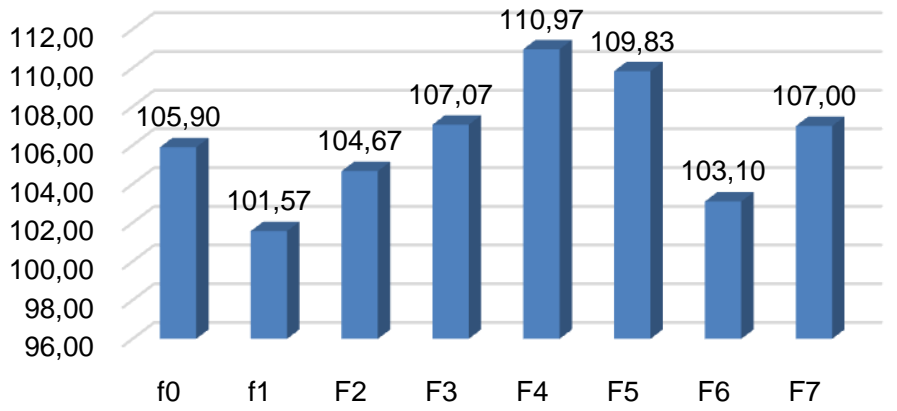

Figure 1 - Average height of rice plants during panicle emergence in phosphorus dose treatment

Figure 1 showed that the dosage treatment of phosphorus $75 \mathrm{~kg} / \mathrm{ha}(\mathrm{f} 4)$ tends to show a higher plant height (110.97) than other treatments. Meanwhile, the dose of phosphorus 30 $\mathrm{kg} / \mathrm{ha}(\mathrm{f} 1)$ showed a lower plant height (101.57) than other treatments.

The results of the observation on the number of productive tillers and their variance were presented in the Appendix 3 and 4 . The variance analysis showed that the dosage treatment of phosphorus had no significant effect on the number of productive tillers of rice. 


\section{Productive Tillers}

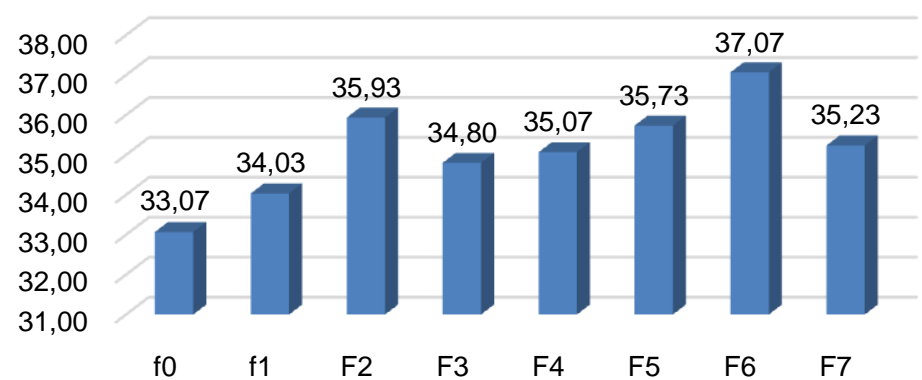

Figure 2 - The Average Number of Productive Tillers of rice plants at the dose of phosphorus treatment

Figure 2 showed that the dosage treatment of phosphor $180 \mathrm{~kg} / \mathrm{ha}(\mathrm{f} 6)$ tends to show a higher number of productive tillers (37.07) than other treatments. While the control without treatment (f0) showed a lower number of productive tillers (33.07) than other treatments.

The observation result of the number of grains per panicle and their variance were presented in the Appendix 5 and 6 . The analysis of variance showed that the dose of phosphorus treatment has no significant effect on the number of grains per panicle.

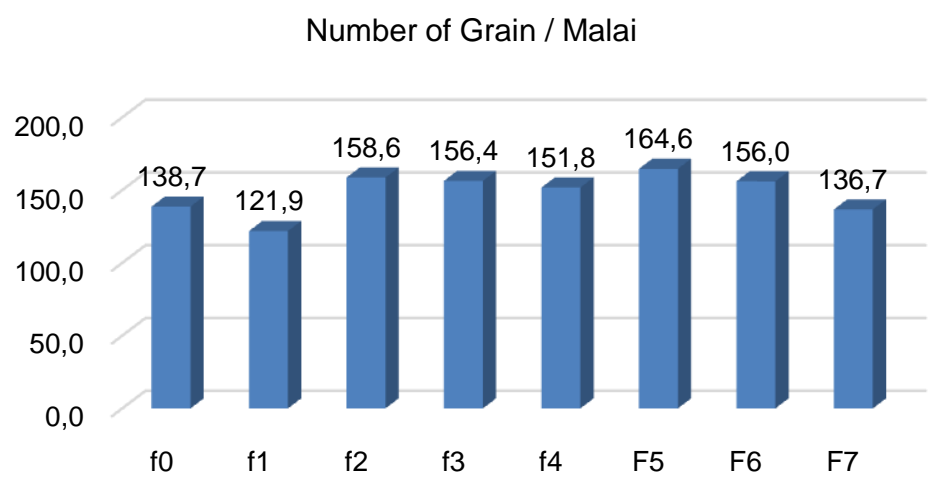

Figure 3 - The Average Number of Grain per Panicle of rice plants in the phosphorus dose treatment

Figure 3 showed that the dosage treatment of Phosphor $150 \mathrm{~kg} / \mathrm{ha}(\mathrm{f} 5)$ tends to show a higher number of grain per panicle (164.6) than other treatments. Meanwhile, $30 \mathrm{~kg} / \mathrm{ha}$ (f1) treatment showed a lower number of grain per panicle (121.9) compared to other treatments.

The results of the observation on the number of empty seeds per panicle and their variance were presented in the Appendix 7 and 8 tables.

Table 1 - Average Number of Empty Seeds per Panicle Treatment of Phosphorus Doses in Rice Plants

\begin{tabular}{|c|c|c|}
\hline Treatment & Average & NP. BNJ $\alpha 0.05$ \\
\hline$f 6$ & $8.90^{\mathrm{a}}$ & \\
\hline $\mathrm{f} 7$ & $10.30^{\mathrm{ab}}$ & \\
\hline $\mathrm{f} 4$ & $10.43^{\mathrm{ab}}$ & \multirow{3}{*}{9.03} \\
\hline $\mathrm{f} 5$ & $12.53^{\mathrm{ab}}$ \\
\hline $\mathrm{f3}$ & $14.70^{\mathrm{ab}}$ \\
\hline $\mathrm{f0}$ & $15.00^{\mathrm{ab}}$ \\
\hline $\mathrm{f} 1$ & $15.97^{\mathrm{ab}}$ & \\
\hline $\mathrm{f} 2$ & $19.00^{\mathrm{b}}$ & \\
\hline
\end{tabular}

Note: The numbers followed by different letters mean significantly different at the BNJ test level $\alpha=0.05$. 
Table 1 showed that the dosage treatment of Phosphor $180 \mathrm{~kg} /$ ha (f6) was significantly different from the dosage of Phosphor $60 \mathrm{~kg} / \mathrm{ha}(\mathrm{f} 2)$ but it was not significantly different compared to treatment $\mathrm{f} 7, \mathrm{f} 4, \mathrm{f} 5, \mathrm{f} 3, \mathrm{f} 0$ and $\mathrm{f} 1$ on the number of empty seeds per rice plants panicle.

The results of the observation of grain weight per 1000 seeds and their variance were presented in the Appendix 9 and 10. The variance analysis showed that the dose of phosphorus treatment had no significant effect on the weight of grain per 1000 seeds.

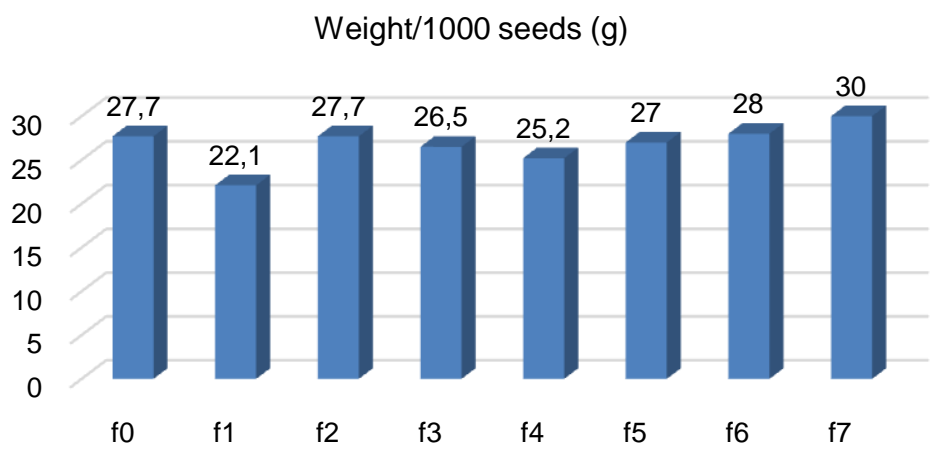

Figure 4 - Average Weight per 1000 rice seeds at phosphorus dose treatment

Figure 4 shows that the treatment dose of phosphor $210 \mathrm{~kg} / \mathrm{ha}(\mathrm{f} 7)$ tends to show a higher amount of grain weight per 1000 seeds (30.0) than other treatments. Meanwhile, 30 $\mathrm{kg} / \mathrm{ha}(\mathrm{f} 1)$ treatment showed a lower number of grain per panicle (22.1) than other treatments.

The results of observations of dry grain harvested dry grain weight per plot and its variance were presented in the Appendix 11 and 12. The analysis of variance showed that the dose of phosphorus treatment has a significant effect on the weight of harvested dry grain per plot.

Table 2 - Average weight of harvested dry grain per plot of phosphorus dose treatment on rice plants

\begin{tabular}{|c|c|c|}
\hline Treatment & Average & NP. BNJ $\alpha 0.05$ \\
\hline$f 5$ & $7.47^{\mathrm{a}}$ & \\
\hline $\mathrm{f} 6$ & $7.40^{\mathrm{a}}$ & \multirow{2}{*}{0.76} \\
\hline $\mathrm{f} 7$ & $7.20^{\mathrm{ab}}$ & \\
\hline $\mathrm{f} 4$ & $7.13^{\mathrm{ab}}$ & \\
\hline $\mathrm{f} 2$ & $7.13^{\mathrm{ab}}$ & \\
\hline $\mathrm{f3}$ & $7.00^{\mathrm{ab}}$ & \\
\hline $\mathrm{f} 1$ & $6.83^{\mathrm{ab}}$ & \\
\hline
\end{tabular}

Note: The numbers followed by different letters mean significantly different at the $B N J$ test level $\alpha=0.05$.

Table 2 showed that the dosage treatment of Phosphor $150 \mathrm{~kg} /$ ha (f5) was significantly different than without treatment (control) (f0) but it was not significantly different from the treatment of $f 6, f 7, f 4, f 2, f 3$ and $f 1$ on the weight of per plot harvested dry grain.

Table 3 - The Average Weight of Harvested Dry per ha of Phosphorus Dose Treatment in Rice Plants

\begin{tabular}{|c|c|c|}
\hline Treatment & Average & \multirow{2}{*}{ NP. BNJ $a 0.05$} \\
\hline $\mathrm{f5}$ & $8.30^{\mathrm{a}}$ & \\
\hline $\mathrm{f} 6$ & $8.22^{\mathrm{a}}$ & \multirow{2}{*}{0.86} \\
\hline $\mathrm{f} 7$ & $8.00^{\mathrm{ab}}$ \\
\hline $\mathrm{f} 4$ & $7.93^{\mathrm{ab}}$ & \\
\hline $\mathrm{f} 2$ & $7.93^{\mathrm{ab}}$ \\
\hline $\mathrm{f} 3$ & $7.78^{\mathrm{ab}}$ & \\
\hline $\mathrm{f} 1$ & $7.59^{\mathrm{ab}}$ & \\
\hline $\mathrm{f0}$ & $7.30^{\mathrm{b}}$ & \\
\hline
\end{tabular}

Note: The numbers followed by different letters mean significantly different at the BNJ test level $\alpha=0.05$. 
The results of observations on the weight of dry grain harvested per ha and its variance were presented in the Appendix 13 and 14. The analysis of variance showed that the dose of phosphorus treatment has a significant effect on the weight of dry grain harvested per ha.

Table 3 shows that the dosage treatment of Phosphor $150 \mathrm{~kg} / \mathrm{ha}(\mathrm{f} 5)$ was significantly different than without treatment (control) ( $\mathrm{fO}$ ) but was not significantly different from treatment $f 6, f 7, f 4, f 2, f 3$ and $f 1$ on the weight of dry grain harvested per ha.

\section{CONCLUSION}

The application of phosphorus fertilizer did not have a significant effect on plant height, number of productive tillers, number of grain / panicle and weight / 1000 seeds.

Giving a dosage of phosphorus fertilizer of $180 \mathrm{~kg} /$ ha can reduce the number of empty seeds / panicles in rice plants.

Giving a dose of phosphorus fertilizer of $150 \mathrm{~kg} / \mathrm{ha}$ can increase the dry weight of the harvest / plot and the dry weight of the harvest / ha of rice plants.

\section{REFERENCES}

1. Adimihardja, A. (2008). Soil Conservation Technology and Strategy in the Framework of Agricultural Revitalization. Agricultural Innovation Development, 1 (2), 105-124.

2. Statistics Indonesia, 2018. National Grain Production. Ministry of Agriculture of the Republic of Indonesia. Jakarta.

3. Soil Research Institute. 2003. Technical Instructions for Calibration of P and K Soil Test on Dry Land for Corn Crops. Soil Research Institute, Center Research and Development of Soil and Agro-climate, Bogor.

4. Buckman H.O and N.C. Brady, 2002.Soil Science (Soegiman Translation). BrataAksara, Yogyakarta.

5. Agriculture department. 2016. Rice Cultivation. Agricultural Research and Development Agency. Jakarta.

6. Department of Agriculture, 2013.General Guidelines for Application of Alternative Fertilizers in Food Crops and Horticulture. Directorate General of Food Plants and Horticulture. Jakarta.

7. Hanafiah, K.A. 2005.Basics of Soil Science.PT. Raja Grafindo Persada. Jakarta

8. Haryanto, D. 2016. Still Identification of Weeds in Tidal Rice Farming and Contribution to Biodiversity. Raden Fatah Islamic University, Palembang.

9. Novizan. 2001. Guidelines for Effective Fertilization. Agro Media Pustaka. Jakarta

10. Normahani, 2015.Knowing Phosphate Fertilizer and Its Functions for Plants. Swamp Land Agricultural Research Institute. New Bnjar. South Borneo.

11. Pinus Lingga. 2012. Instructions for the use of fertilizers. Spreader, Surabaya. Purnamaningsih, R. 2006. Callus Induction and Optimization of Regeneration of Four Rice Varieties through In Vitro Culture. Center for Research and Supervision of Biotechnology and Genetic Resources in Bogor Agriculture. Journal of Agro Biogen 2 (2): $74-80$.

12. Ismunadji, Faqi Ahmad $M$ and Isral Las, 2000.Environment of Rice Plants.Editors Soejipto, Parsiharjono Syam and AdiWidjo. Center for Food Crops Research and Development, Bogor.

13. Ismunadji, 2000.Mineral Nutrient of Rice Plants. Agricultural Research and Development Agency. Center for Food Crops Research and Development, Bogor.

14. Syarief S, 2014. Agricultural Soil Fertility and Fertilization. Pustaka Buana, Bandung.

15. Salisbury, F.B \& C.W. Ross. 1995. Plant Physiology. Bandung: ITB Press.

16. Siregar, H, 2005. Rice Cultivation in Indonesia, SastraHudaya, Jakarta.

17. Sugiatmo. 2001. Research Report on the Effect of Combination of Fertilizer (urea, TSP and $\mathrm{KCl}$ Wonder Liquid) on Growth and Yield of Three Rice Varieties. Sebelas Maret University Faculty of Agriculture. Surakarta. 
18. Suparyono and Agus Setyono, 2009. Overcoming Problems of Rice Cultivation. Spreader, Jakarta.

19. Sutriadi, M.T., Rochayati and Rachman, A. 2010.Utilization of Natural Phosphates from Environmental Aspects.Agricultural Research and Development Agency, Jakarta.

20. Qibtiyah, M,. 2015. Definition and Role of Phosphorus nutrients for Plants. Department of Agrotechnology. Faculty of Agriculture. DarulUlum Islamic University in Lamongan.

21. Tannock, J \& Wessel, CL 2003, 'Determination of carbofuran residues and metabolits in plant material', Pestic. Sci., Vol. 25, pp. 238-43.

22. Zubaidah, $Y$ and Munir, R. 2007. Phosphorus (P) Fertilization Activities in Rice Fields with Medium P Content. West Sumatra AIAT.Solum Journal Vol 4 No.1 January 2007: 14 ISSN 1829-7994. 